\title{
The Role of Instagram in Establishing Indoglish at A Vocational School
}

\author{
Afifah istiqomah ${ }^{1}$, Sumarwati ${ }^{2}$, and Budhi Setiawan ${ }^{3}$ \\ \{afifahistiqomah@student.uns.ac.id ${ }^{1}$,watik_uns@ymail.com ${ }^{2}$, buset.74@gmail.com ${ }^{3}$ \} \\ 1,2,3 Universitas Sebelas Maret, Surakarta, Indonesia
}

\begin{abstract}
Social media has an influence on language changes in society which has created the formation of Indoglish culture especially among vocational students. One of the most popular social media for the public is Instagram. The purpose of this study was to reveal the use of Indoglish among students at Muhammadiyah 2 Vocational School of Surakarta. The method used was descriptive qualitative. The research data was retrieved from Instagram. Data analysis techniques used the interactive models of Miles and Huberman which consisted of four stages, namely data collection, data reduction, data analysis, and verification or drawing conclusions. The data collection technique used purposive sampling with a contextual approach. The results of this study indicated that the vocabularies or terms among the students which were popularized by Instagram social media were: (DM) direct message, (Follback) Follow Back, Endorse, Story, Status, Promote, Netizen, and Caption. In depth, this research led to three findings, they were 1) terms or vocabularies in foreign language (English) existing in social media, 2) the formation of Indoglish in the vocational school context and 3) the examples found in the vocational school.
\end{abstract}

Keywords: indoglish, instagram, social media, vocational school

\section{INTRODUCTION}

In its development, communication can be done through various media including the internet. Through the internet communication between people is getting easier, both with familiar people and unknown people from various parts of the world. The initiation of social media makes the pattern of people's behavior experiencing a shift in the existing culture, ethics and norms [1]. The term social media itself is composed of two words, namely "media" and "social" [2]. One of the social media facilities which was found on the internet includes social networks known as Instagram. Instagram is generally known as a novel photo-sharing social networking platform [3]. Another view argues that Instagram is an application that is used to distribute photos and videos [4]. Instagram social media has become one and part of the people's lifestyle, because almost every community activity is enshrined and published on the Instagram [5]. 
Instagram becomes the social media which is currently in great demand by the public today. A recent survey shows that Instagram is the second most popular social media platform, with 59\% of online users aged 18-29 using Instagram [6]. Many Instagram users aim to express their personalities through Instagram social media, one of which is to fulfill their pleasures and satisfaction through uploading photos telling about what they did. In terms of uploading photos, Instagram enables providing freedom of expression [7].

Social media is an online media that supports social interaction. Social media uses webbased technology that converts communication into an interactive dialogue [8]. Social media is independent media since it is not owned and controlled by political rulers like some of the conventional media in Indonesia [9]. Social media also offers instant entertainment involving mass (netizen). One of the entertainment applications used is Sing! Karaoke by Smule. The digital native can share karaoke videos into their social media content like Instagram or Facebook [10]. The digital age presents various conveniences that were previously unimaginable. Many things which were initially very complex are now simple with the existence of technology. Digital technology is used by the community to earn income or just for amusement [11].

Entering the era of globalization, adolescents are among those who often use internet media especially social media as a means to find information, entertainment and communication with friends on social networking sites [12]. With this phenomenon, language becomes symbols that are used to express opinion, ideas, and feelings to others. Humans cannot live without using language, either oral or written language [13]. This condition is like a convention that changes how to communicate in the digital era like present days. In the past, introductions were done in a conventional way, namely (usually) accompanied by exchanging business cards, today every time we meet new people tend to exchange account addresses or make friends on social media [2].

Today, many people use social media such as Instagram, and so on as a communication tool. In communicating people usually tend to use two languages such as Indonesian and English which are usually abbreviated as Indoglish. Indoglish is a term often used to refer the English language which is nuanced by Indonesian culture. Indoglish [14] or it can be said that this form is a distinctive form, in which the form is in English but its meaning has entered the Indonesian language culture [15]. Another definition explains Indoglish as a term that is usually used to express the English use in Indonesian culture .

In sociolinguistics it is known as code switching and borrowing. In addition, when we learn more about this phenomenon; Indoglish is a unique and distinctive form where a mixture of English and Indonesian. Indoglish becomes a certain form because Indoglish cannot be evidently seen as English or Indonesian [14]. The "Indoglish" and "Jawanesia" phenomena are actually more than just linguistic phenomena in multilingual societies called code-mixing. Thus, it cannot be said that this linguistic phenomenon is the same as mixed code even though many people say that the linguistic phenomenon is identical [16].

Indonesian teenagers often follow social media developments regarding words that are considered as current and trendy. Among adolescents, including vocational students, they often insert words that exist in popular social media such as on Instagram. Instagram can also provide inspiration for users and can also increase creativity, because Instagram has features that can make photos more beautiful, more artistic and finer [12]. Everyone has social media even more than one social media like Facebook, Whatsapp, BBM (blackberry messenger), Instagram, Line, and Twitter which function to communicate [17].

In the social media, there are comments from netizen which use a variety of languages, including the rise of foreign languages that adorn social media in Indonesia. Foreign language, 
especially English, is integrated with Indonesian, which is later referred to as Indoglish culture. The existence of vocabulary from English on Instagram greatly influences the Indoglish culture that is formed in the community, especially among vocational students. Indoglish becomes a phenomenon of mixing Indonesian and English in written language or oral language.

Based on the assertion above, the researchers focused more on the investigation of Instagram social media among vocational students to gain a thorough discussion. This research is sociolinguistic. The problem discussed was how the use of language variants employed by vocational students on their Instagram status and comments. The purpose of this research is to find and explain the use of language variants among vocational students on Instagram status and comments on the internet.

\section{METHOD}

This study used a qualitative descriptive method. This research data comes from internet media, specifically on Instagram social networks. In providing data, researchers opened the Instagram social networking site. After that, the researchers copied the use of language on Instagram by copying it. The researchers took representative data with purposive sampling technique, which meant that this study was only focused on students of Surakarta Muhammadiyah 2 Vocational School. The approach used was the contextual method. Contextual method was meant to analyze and describe data based on social phenomena or social situations and symptoms [14]. In other words, the analysis was carried out by connecting between the speech and discourse of the physical and social context. After the data was collected, the researchers classified the data that had certain similarities related to language variations [14].

\section{RESEARCH RESULTS AND DISCUSSION}

This research was carried out by using relevant theories. Some theories about the culture of social media done by the Indonesian people and also the language used in social media were used to study the Indoglish language. The Indoglish was specifically exhibited by students of the Muhammadiyah 2 Vocational School in Surakarta.

\subsection{Words or Foreign Language Terms (English) on Instagram}

As Indonesian citizens, the terms in Indonesian must be well known by the wider community as the language users. The Language Development and Guidance Agency has made Indonesian terms as an equation of foreign terms, in the fields of education, information technology, mass communication, economic and business, medicine, forestry, and in international relations. In the glossary of the Indonesia Dictionary (Kamus Besar Bahasa Indonesia) all these terms already exist in it. However, not all of these terms are understood by the public when viewed from a very large number of people who do not know the new terms or the equivalent of foreign languages into the Indonesian language.

The spread of foreign terms which are actually familiar to Indonesian users is caused by the very rapid technological development, where in this millennial era everything is online base. All activities in this millennium such as social activities, economic activities (buying and selling online) are done online. This is supported by the large number of social media and ecommerce that are increasingly favored by the wider community, including among vocational students. 
Online-based social activities can be done by anyone through social media. The increasing proliferation of social media in the community makes social activities easier and wider. Social activities such as friendships, discussion activities, and exchange of information and experience are now not only done directly but also done through social media.

In Indonesia, one of the popular social media is Instagram. Social media itself greatly influences the language culture of the society because on social media there are many words or terms of foreign languages that are very familiar to the community and eventually used by the community in daily life.

Some vocabularies or terms in the community which are popularized by social media are (1) Instagram: (DM) direct message, (Folback) Follow Back, Endorse, Story, Status, Promote, Netizen and Caption.

\subsection{Formation of the Indoglish Language in Vocational School}

The existence and spread of vocabularies or terms in the community cannot be separated from the role of the media. The term can be widespread and recognized by the public through the media. For example, the term used in the field of informatics which progress is very fast can be easily recognized and used by the language community through the media. The words download and upload, for example, are spread quickly with Indonesian terms to download (unduh) and upload (unggah). Likewise with terms in other fields, such as in the field of information technology the terms page and e-mail which are equivalent to the terms laman and pos-el are widely known by the public. The terms are spread and accepted by the community because the existence of media as information source that always tells the latest and fastest. If in the past, introductions were done in a conventional way, namely (usually) accompanied by exchanging business cards, now every time we meet new people tend to exchange account addresses or make friends on social media. Along with the rapid development of technology, a new media emerged called social media.

Social media is a network media in which users can easily participate in, share, communicate and create their own media content. Social media consists of various forms, such as magazines, internet forums, weblogs, social blogs, micro blogging, wikis, podcasts, photos or images, videos, rankings, and social bookmarks. The development of social media has also created social networking sites that are followed by many users. Social media is now used as a channel or means of social interconnection on a net basis in cyberspace (internet). Social media users can communicate, interact, send messages, share, and build networks. One of popular social media used in Indonesia is Instragram. There are also many terms emerging and directly used by the language user community because it is displayed by social media. Hereby some new vocabularies or terms in foreign languages that are more familiar to the people and shape Indoglish culture in the community, especially among vocational students which are popularized by social media: (DM) Direct Message, (Folback) Follow Back, Endorse, Story, Status, Follow, Promote, Fix, (OTW) On The Way, Netizens, and Blow Up. The foreign terms have now been known by the wider community of social media users, such as vocational students or the general public. The existence of Indoglish language has been very attached to the community, especially among students and vocational students whose daily lives use the Indoglish language because of the effects of foreign languages that occur on social media. Today's millennial generations are very easily imitating the social media "follow along", especially, recently Instagram artists appear or often referred to as selebgram who often speaks on social media so that social media users follow the "English tongue" practice done by the celebritie. They mixed foreign words that formed Indoglish culture in the community, especially among vocational students. 


\subsection{Examples of Indoglish Language in the Vocational Student Environment}

The author conducted research regarding the spread of Indoglish culture in the use of everyday language, particularly among students of Surakarta Muhammadiyah 2 Vocational School. In this study there were popular foreign terms transferred through the role of social media as the conveyor.

The results of the study showed that the Indonesian terms which are the equivalent of a foreign language were still rarely known by vocational students as native Indonesian language users [17]. They were more comfortable and familiar to use or mix foreign language words or terms which actually have equivalents in Indonesian. Mixing foreign languages especially English with Indonesian is commonly referred to as Indo-English or Indoglish. Here is an example of a conversation quoted from some vocational students related to Indoglish culture in everyday conversation. In this study some examples of the use of Indoglish was found among students of Surakarta Muhammadiyah 2 Vocational School.

\section{Excerpt 1:}

(1) Siswa 1 : "Hai, Sist sudah Follow Instagram ku belum ?"

Student 1 : "Hi, Sist (sister), have you followed my Instagram yet?"

(2) Siswa 2 : "Belum nih, emang nama acount Instagram mu apa?

Student 2 : "Not yet, what is your Instagram account name?

(3) Siswa $1:$ look, @ rhasty_18.

Student 1:look, @ rhasty_18.

(4) Siswa 2 : Follow acount Instagram jualanku juga dong, shay...

$$
\text { Student 2: } \quad \text { Follow my commerce Instagram account too, dar.... (Darling) }
$$

(5) Siswa 1 : Apa nama acountnya?

Student 1 : What is the account name?

(6) Siswa 2: @asheeqa

Student 2: @asheeqa

(7) Siswa 1 : Wait, ya sist....

Student 1 : Wait a minute, sist ... (sister)

\section{Excerpt 2:}

(1) Siswa 1

: "Hai guys, kemarin aku diDM sama salah satu clothing line gitu mau endorse produknya dia. Menurut kalian aku ambil gak?"

Student 1

: "Hi guys, yesterday I was DM (contacted) by one of the clothing lines. He wants to endorse his product. Do you think I take the offer or not?"

(2) Siswa 2

: "Wah, ambil aja, lumayaaan."

Student 2

: "Wow, just accept it, it's a fair fortunate."

(3) Siswa 3

: "Iya tuuuh...ambil aja, lumayan loooh, dapet duit sama endorsean barang, sini aku follow akun clothing line-nya. Biar bisaku like foto-fotonya"

Student $3 \quad$ : "Yeah, bro ... just take it, it's a big deal, you get the money and endorsed item, Let me follow the clothing line account. So I can like the photos?

(4) Siswa 1

: "Siap, nanti aku kabari lagi lewat $D M$ "

Student $1 \quad$ : "Sure, I'll let him know again via DM" 


\section{CONCLUSION}

The developments of technology have influenced on the field of language and social life. This development was marked by the emergence of social media. Thus, social media has a huge influence in the field of language, the concrete instance is Instagram social media. Instagram plays an important role in supporting social interaction. In this study, three aspects can be concluded, namely 1) words or terms of foreign languages (English) on Instagram Social Media occurred in the form of direct message (DM), (Folback) Follow Back, Endorse, Story, Status, Promote, Netizens, and Caption. 2) The formation of Indoglish Language in Vocational School has been very attached to the community such as among students in general and especially vocational students in their daily lives. The formation of the Indoglish language is due to the effect of terms in foreign languages that existed on social media. Millennial-age teenagers easily imitated social media and, (3) the examples of Indoglish Language in vocational student environment are follow, DM, clothing line, endorse, and guys.

\section{REFERENCES}

[1] A. S. Cahyono, “79-148-1-Sm (1)," pp. 140-157.

[2] M. Mulawarman and A. D. Nurfitri, "Perilaku Pengguna Media Sosial beserta Implikasinya Ditinjau dari Perspektif Psikologi Sosial Terapan," Bul. Psikol., vol. 25, no. 1, pp. 36-44, 2017.

[3] H. Ting, W. W. P. Ming, E. C. de Run, and S. L. Y. Choo, "Beliefs about the Use of Instagram: An Exploratory Study," Int. J. Bus. Innov., 2015.

[4] A. Irma, “9382-30667-1-Pb,” vol. 4, no. 2, pp. 1-12, 2017.

[5] N. Con, P. Aplicaciones, E. N. Liberación, and A.- Objetivos, “2 , 2 , 3,” vol. 1, no. 1, pp. 1-5, 2017.

[6] B. C. Sakti, M. Yulianto, J. I. Komunikasi, and G. Index, "Penggunaan Media Sosial Instagram Dalam Pembentukan," pp. 1-12, 2013.

[7] B. Mahendra, "Eksistensi Sosial Remaja dalam Instagram (Sebuah Perspektif Komunikasi)," J. Visi Komun., vol. 16, no. 01, pp. 151-160, 2017.

[8] I. Suryani, "Pemanfaatan Media Sosial Sebagai Media Pemasaran Produk Dan Potensi Indonesia Dalam Upaya Mendukung Asean Community 2015. (Studi Social Media Marketing Pada Twitter Kemenparekraf Ri Dan Facebook Disparbud Provinsi Jawa Barat)," J. Komun., vol. 8, no. 2, pp. 123-138, 2017.

[9] N. Kholis, N. Husna, G. Asavitri, and Y. Prisca, "Creating Democratic Society: Howdo Malang's Instagram Influencers Use Their Freedom of Expression and Speech?," 2019.

[10] L. P. Supratman and U. Telkom, "Penggunaan Media Sosial oleh," pp. 47-60, 2009.

[11] E. Amanati, "Bahasa Ekspresif di Instagram ( Bahasa Indonesia)." .

[12] G. Bahasa, "JURNAL WIDYALOKA IKIP WIDYA DARMA | Vol. 5. | NO. 3 | Juli 2018,” vol. 5, no. 3, pp. 261-278, 2018.

[13] N. Setyawati, "Pemakaian Bahasa Gaul Dalam Komunikasi Di Jejaring Sosial," Pemakaian Bhs. Gaul Dalam Komun. Di Jejaring Sos., no. c, pp. 1-28, 2016.

[14] A. Rakhmawati, K. Saddhono, S. Hastuti, and R. Devilito, "A Phenomenon of Indoglish Usage At Universities in Indonesia : Breaking Down the Motives," Int. Semin. Prasasti III Curr. Res. Linguist., pp. 146-152, 2016.

[15] E. Science, "Indoglish as adaptation of english to Indonesian : change of society in big cities of Indonesia Indoglish as adaptation of english to Indonesian : change of society in big cities of Indonesia," 2018.

[16] R. K. Rahardi, “Bahasa 'Indoglish' dan 'Jawanesia' dan Dampaknya Bagi Pemartabatan 
Bahasa Indonesia," Kaji. Linguist. dan Sastra, vol. 26, no. 1, pp. 1-21, 2014.

[17] K. Saddhono and D. Sulaksono, "Indoglish as adaptation of english to Indonesian: change of society in big cities of Indonesia." IOP Conf. Ser.: Ear. and Envi. Sci.. vol. 126 no. 1 IOP Publishing, 2018.

[18] D. Untari, “Eksistensi bahasa jawa dalam wacana,” vol. 2, pp. 147-155, 2017. 